\title{
A Review on Desulfurization Techniques of Liquid Fuels
}

\author{
Gulam Gaush Zeelani ${ }^{1}$, Dr. Sundar Lal Pal ${ }^{2}$ \\ ${ }^{1}$ PG Student, Department of Chemical Engineering, MANIT Bhopal, India \\ ${ }^{2}$ Assistant Professor, Department of Chemical Engineering, MANIT, Bhopal, India
}

\begin{abstract}
Strategies for liquid fuel desulfurization were estimated by reviewing desulfurization literature and critically evaluating the viability of the several methods for liquid fuels. This review paper dealt with various desulfurization technology for liquid fuels such as extractive desulfurization, oxidative desulfurization, biodesulfurization and adsorptive desulfurization to form ultra-clean liquid fuels. This work, therefore, reviews the different approaches and effect of desulfurization on liquid fuels investigating carried out on desulfurization under different process conditions.
\end{abstract}

Keywords: Oxidative desulfurization (ODS), Hydrodesulfurization(HDS), Extractive desulfurization(EDS), Biodesulfurization (BDS), Adsorptive Desulfurization, Sulfur.

\section{Introduction}

Sulfur in liquid fuels is highly undesirable and the sulfur content of many products is strictly regulated. Sulfur reduces the quality of the oil needed to produce final products and by extension the commercial value of the liquid fuel. There are three major types of transportation fuels such as jet fuel, diesel oil, and gasoline which are different in composition and properties. Diesel fuel contains the most refractory sulfur compounds such as Benzothiophene, Dibenzothiophene, and4,6-dimethyldibenzothiophene to the present of sulfur content in these transportation fuels culprit's environmental pollution [1]. The combustion of refractory sulfur-containing compounds present in liquid fuels proceeds to the formation of sulfur oxide. The oxides of sulfur $\left(\mathrm{SO}_{\mathrm{X}}\right)$ account to acid rain and atmospheric pollution, which decreases combustion efficiency fuel and enhance emission of other particles. Therefore, several countries keep stringent legislation to extent sulfur content in liquid fuel, such as in European countries sulfur(S) content <10ppm and in USA <15ppm [2]. Presently, Hydrodesulfurization(HDS) process employed to reduce sulfur content from liquid fuels but it requires high operating condition (Temperature, Pressure) and high hydrogen consumption for sulfur removal [3]. HDS process is very effective to remove aromatic sulfur compounds such as thiols, sulfides, and disulfides but it is not efficient to remove more refractory sulfur compounds are Thiophenes (Ts), benzothiophenes (BTs), dibenzothiophene (DBTs), 4,6dimethyldibenzothiophenes (4,6-DMDBTs) and their alkyl derivatives. So researchers developed alternative technology to reduce the sulfur content in liquid fuel to ultra-low as adsorptive desulfurization (ADS), oxidative desulfurization (ODS), hydrodesulfurization(HDS), biodesulfurization (BDS), extractive desulfurization(EDS), etc. The sulfur containing compounds are encountered in many areas in oil refinery and common type of refractory sulfur compounds in liquid fuels. The concentration of refractory sulfur compounds varies due to boiling point changes. The refractory sulfur compound becomes more refractory with increasing of boiling point, the dominant sulfur compounds such as thiols, thiophene, and sulfides in naphtha to substituted benzothiophenic compounds in distillate. Recent studies on desulfurization show that sulfur content in the environment is increasing and could gesture series health consequences like the respiratory disease such as emphysema [4].

\section{Desulfurization Techniques}

\subsection{Hydrodesulfurization (HDS)}

Hydrodesulfurization process is most the widely used method in the petroleum industry to reduce sulfur content in crude oil. Usually, HDS process is operated by co-feeding of crude oil and hydrogen in a fixed bed reactor stuffed with relevant Hydrodesulfurization catalyst. At the time of conventional Hydrodesulfurization, the organic sulfur compounds primarily converted to $\mathrm{H}_{2} \mathrm{~S}$ with the reactor temperature ranges $300^{\circ} \mathrm{C}$ to $350^{\circ} \mathrm{C}$ and pressure ranges 15 to 90 bar by used of Hydrodesulfurization catalyst $\left(\mathrm{NiMo} / \mathrm{Al}_{2} \mathrm{O}_{3}\right.$, $\mathrm{CoMo} / \mathrm{Al}_{2} \mathrm{O}_{3}$, etc.) and additional recycling of $\mathrm{H}_{2} \mathrm{~S}$ by clause process to achieve elemental sulfur [6].

HDS process is most convenient method to remove aliphatic sulfur compounds such as mercaptans(RSH), sulfides(RSR), and disulfides(RSSR) but this is not appropriate process to remove more refractory sulfur containing compounds such as thiophene, benzothiophene(DBT), 4,6-dimethyldibenzothiophene(4,6-DMDBT) from fuel oil [7]. In HDS process aliphatic sulfur is more reactive and removed completely from liquid fuel according to following mechanisms [4]:

$$
\begin{array}{lllll}
\text { Mercaptans: } & \mathrm{R}-\mathrm{S}-\mathrm{H} & \mathrm{R}-\mathrm{S}-\mathrm{H}+\mathrm{H}_{2} & \longrightarrow & \mathrm{R}-\mathrm{H}+\mathrm{H}_{2} \mathrm{~S} \\
\text { Sulfides: } & \mathrm{R}_{1}-\mathrm{S}-\mathrm{R}_{2} & \mathrm{R}_{1}-\mathrm{S}-\mathrm{R}_{2}+2 \mathrm{H}_{2} & \longrightarrow & \mathrm{R}_{1}-\mathrm{H}+\mathrm{R}_{2}-\mathrm{H}+\mathrm{H}_{2} \mathrm{~S} \\
\text { Disulfides: } & \mathrm{R}_{1}-\mathrm{S}-\mathrm{S}-\mathrm{R}_{2} & \mathrm{R}_{1}-\mathrm{S}-\mathrm{S}-\mathrm{R}_{2}+3 \mathrm{H}_{2} & \longrightarrow & \mathrm{R}_{1}-\mathrm{H}+\mathrm{R}_{2}-\mathrm{H}+2 \mathrm{H}_{2} \mathrm{~S}
\end{array}
$$

[8] In general the reaction mechanism of DBT through HDS process was suggested via two main routes Fig 1: one is direct desulfurization route, where sulfur removal occurs without affecting the aromatic rings and another is 


\section{International Journal of Science and Research (IJSR) \\ ISSN (Online): 2319-7064}

Index Copernicus Value (2013): 6.14 | Impact Factor (2015): 6.391

desulfurization occurs via hydrogenation route, in which refractory sulfur compounds (DBT) are preferentially hydrogenated in the form of $4 \mathrm{H}$ or $6 \mathrm{H}-\mathrm{DBT}$ and these intermediates are subsequently desulfurized. Thus, sulfur removal rate of refractory sulfur compounds achieved highest degree in hydrogenation route.

Figure 1: Direct desulfurization and Hydrogenation route for Hydrodesulfurization of DBT.

Even though HDS process is still the main technology applied in the petroleum refining industry some advantages appear as it described below [9]

a) Severe reactor conditions such as high temperature and pressure required to process more refractory sulfur compounds.

b) Use of expensive catalyst; due to the high organometallic content of heavy hydrocarbon the catalyst life shortens as the metal (Nickel, Vanadium) sulfides causes deposit formation on the catalysts.

c) Fouling and coking, which causes catalyst deactivation.

Wang et al. [7] studied the reactivity of refractory sulfur compounds which varies with their structure and sulfur atom environment. Low boiling sulfur containing compounds such as aliphatic refractory sulfur compounds (mercaptans, sulfides, and disulfides). The aliphatic sulfur compounds are very active in Hydrodesulfurization (HDS) process and these compounds can be easily removed from liquid fuel. The refractory sulfur compounds activities in HDS process are as follows: order (from least reactive to more reactive) 4,6$\mathrm{DMDBT}>\mathrm{DBT}>\mathrm{BT}>$ thiophene.

\subsection{Oxidative Desulfurization (ODS)}

The deep desulfurization of liquid fuel has drawn much attention for new regulations requiring ( $<10 \mathrm{ppm}$ sulfur) and it is difficult and very costly to use Hydrodesulfurization process for reduction of sulfur content from liquid fuel. In order to find the new regulation, various alternative desulfurization technologies approach such as extractive desulfurization, oxidative desulfurization, desulfurization, adsorption desulfurization and biodesulfurization etc. [10]. Among these desulfurization technologies, oxidative desulfurization (ODS) is the most suitable technique to achieve ultra low sulfur containing compound fuel oils. The main advantage of this process is that it operates at mild operating condition (temperature, Pressure), no need of hydrogen and low operating cost. ODS process has been most attractive method among researchers for removal of refractory sulfur compounds BT, DBT, 4,6-DMDBT etc. [11].

In ODS process various oxidizing agent was used such as ozone, molecular oxygen, hydrogen peroxide $\left(\mathrm{H}_{2} \mathrm{O}_{2}\right)$, organic peracides etc. among these oxidizing agent hydrogen peroxide $\left(\mathrm{H}_{2} \mathrm{O}_{2}\right)$ mostly used one, because of its low cost, environmentally benign and active oxygen content. ODS process preferentially operated in two stages shown in the Fig 2 (i) oxidation of refractory sulfur compounds into sulfones and (ii) separation by using of extraction and adsorption method into a polar solvent [12].

Figure 2: Oxidative Desulfurization process of sulfur Compound dibenzothiophene (DBT)to sulfone

Jianghua Qiu et al. [13] prepared $\mathrm{H}_{3} \mathrm{PMo}_{12} \mathrm{O}_{40} / \mathrm{SiO}_{2}$ catalyst for catalytic oxidative desulfurization of fuel oil. The $\mathrm{HPMo} / \mathrm{SiO}_{2}$ catalysts were very efficient for the oxidation of DBT and BT in the model fuel oil by using of $\mathrm{H}_{2} \mathrm{O}_{2}$ as the oxidant. Under the condition of catalyst dosage $0.05 \mathrm{~g}, \mathrm{H}_{2} \mathrm{O}_{2}$ dosage $0.05 \mathrm{~mL}$ and reaction temperature $70^{\circ} \mathrm{C}$, the conversion rate of DBT reached $100 \%$ only in 60 min and that of BT conversion achieved to $99.2 \%$ in $150 \mathrm{~min}$. The kinetic studies indicate that the oxidative desulfurization of DBT and BT was the pseudo-first-order reaction. They also studied the activation energies of BT and DBT was 40.5 $\mathrm{kJ} / \mathrm{mol}$ and $33.0 \mathrm{~kJ} / \mathrm{mol}$, respectively.

N. Jose et al. [14] studied catalytic oxidative desulfurization of the refractory sulfur compound present in the liquid fuel. The investigators used a titanium silicate (TS-1) catalyst for ODS process and sulfur removal achieved to $22 \%$ in $240 \mathrm{~min}$ by addition of $1.05 \mathrm{wt} \%$ copper in titanium silicate. They also have done experiments by using the box-behnken method to estimate processes operating condition such as reaction temperature, the catalyst used, and ratio of hydrogen peroxide and thiophene and their values are $70^{\circ} \mathrm{C}, 0.45 \mathrm{~g}$, and 19.9 mole respectively to the sulfur reduction achieved to 93\%. Yuhua et al. [11] applied catalytic oxidative desulfurization (ODS) for desulfurization of refractory sulfur compounds BT, DBT, 4,6-DMDBT. They also studied that refractory sulfur compound can be oxidized into sulfones by using of hydrogen peroxide oxidant $\left(\mathrm{H}_{2} \mathrm{O}_{2}\right)$ over $14 \mathrm{wt} \%$ $\mathrm{MoO}_{3} / \gamma-\mathrm{Al}_{2} \mathrm{O}_{3}$ catalyst under mild operating conditions, sulfur concentration achieved to $100 \%$ in $2 \mathrm{~h}$. Uttam et al. [16] investigated the oxidation of sulfur compounds in model oil (DBT dissolved in n-octane) by using of hydrogen peroxide $\left(\mathrm{H}_{2} \mathrm{O}_{2}\right)$ as an oxidizing agent in the presence of nanocrystal line Ti-beta catalyst. Under mild operating condition such as temperature $100^{\circ} \mathrm{C}$, atmospheric pressure, and mole ratio of $\mathrm{H}_{2} \mathrm{O}_{2}$ to $\mathrm{S}$ of $10: 1$ more than $93.5 \%$ of Dibenzothiophene could have oxidized in the model oil. Authors studied the catalytic activity of Ti-beta catalyst, there is significant reduction after the first cycle in DBT conversion.

\subsection{Extractive desulfurization (EDS)}

Desulfurization via extraction depends on the solubility of the refractory sulfur compound in certain solvents. Babich et al. [17] studies describe general process flow of the 


\section{International Journal of Science and Research (IJSR) \\ ISSN (Online): 2319-7064}

Index Copernicus Value (2013): 6.14 | Impact Factor (2015): 6.391

desulfurization via extraction method as shown in the figure [3]. In the mixing tank feedstock is mixed with the solvent and the refractory sulfur compounds are extracted into solvent because of their higher solubility in the solvent. Then in the separator section, hydrocarbon is separated from the solvent. After the separation, the treated hydrocarbon is blended to the final product or transferred to distillation for further transformation or treatments. During distillation refractory, sulfur compounds are separated from the solvent and the recovered solvent is recycled to mixing tanks. The most attractive characteristic of extractive desulfurization process, it operates at mild operating conditions and no need of hydrogen. The process does not change the chemical structure of fuel components. The efficiency of the extractive desulfurization process is limited by the solubility of the refractory sulfur compounds in the solvent. So a choice of solvent is very important to increase the efficiency of extraction desulfurization process such as solvent should have the different boiling point than sulfur compounds and solvent should be cost effective in order to make feasible for industrial applications. Various solvent has been tried such as acetone, ethanol, and polyethylene glycols, which resulted in $50-90 \%$ desulfurization depending on the number of cycles of the process [18].

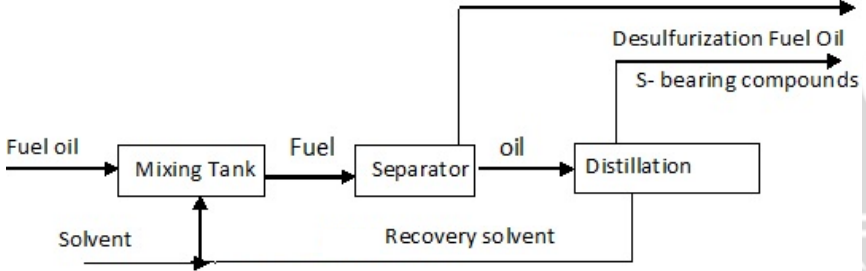

Figure 3: General process for extractive desulfurization [4]

Various studies have been investigated on the desulfurization via extraction for the removal of the sulfur compound from liquid fuels. Light oils were mixed with different organic solvents such as DMSO, acetonitrile and tetramethylenesulfone at ambient conditions in order to examine he sulfur compounds and aromatic extractability [19]. Topalova et al. studied the two stage desulfurization via extraction with dimethylformamide as a solvent. The result shows that the sulfur content in diesel oil was reduced from $2 \mathrm{wt} \%$ to $0.33 \mathrm{wt} \%$ [20]. Xiaochun Chen et al. [21] studied desulfurization of liquid fuels by extraction with Lewis acidic ILs 1-butyl-3-methylimidazolium chloride

$\left(\mathrm{ZnCl}_{2}\left([\mathrm{Bmim}] \mathrm{Cl} / \mathrm{ZnCl}_{2}\right)\right.$. The author also tested the activity of ionic liquid for different desulfurization. The investigators also reported that liquid fuel could be obtained after six stage extraction are obtained at $25^{\circ} \mathrm{C}$, ionic liquid/oil ratio of 1 , with the yield of thiophene(TS), Dibenzothiophene(DBT) liquid fuels reaches to $93.8 \%$ and $95.9 \%$ in $30 \mathrm{~min}$. They also investigated the reusability of ionic liquid in desulfurization process.

Swapnil A. Dharaskar et al. [3] reported the extractive desulfurization process of liquid fuels by using of lewisbased ionic liquid $\left([\mathrm{Bmim}] \mathrm{Cl} / \mathrm{FeCl}_{3}\right)$. They also reported that desulfurization via extraction for removal of sulfur compounds from liquid fuels in single extraction at mass ratio of model liquid fuels to ionic liquid $5: 1$ at $30^{\circ} \mathrm{C}$ in the water bath for $30 \mathrm{~min}$ and sulfur reduction achieved to $75.6 \%$. They also found that ionic liquid reused without regeneration with the efficiency of $47.3 \%$. Datsevich et al. [22] have studied the profound desulfurization of diesel oil by extraction desulfurization process through ionic liquids. In this study ionic liquid(chloroaluminate) was used and the result showed that by using of five stage extraction process for removal of the sulfur compound from diesel oil achieved to $80 \%$ at the temperature of $60^{\circ} \mathrm{C}$.

\subsection{Adsorptive desulfurization (ADS)}

Desulfurization via adsorption is based on the capability of sorbent material to particular adsorb refractory sulfur compounds. Adsorptive desulfurization considered as most economical technology among different desulfurization techniques due to simple operating condition and regenrability of adsorbents such as metal oxides, alumina, metal sulfides, zeolite, silica and activated carbon [23-24]. The adsorptive desulfurization can be approached in two ways: adsorptive desulfurization and reactive adsorption desulfurization. (i)Adsorptive desulfurization occurs through physical adsorption of refractory sulfur compounds on the solid adsorbent surface. Regeneration usually did by thermally spent sorbent with desorbent (ii) reactive adsorption desulfurization based on the interaction of organic sulfur compounds and the adsorbent. Sulfur chemically bounded to the sorbent going in the form of sulfides, as newly formed hydrocarbon compound released into the purified fuel stream. Regeneration of the spent adsorbents results in sulfur elimination in the form of $\mathrm{H}_{2} \mathrm{~S}, \mathrm{~S}$, etc. The Efficiency of adsorptive desulfurization mainly determined by the sorbent material, selectively to refractory sulfur compounds with relative to hydrocarbons, durability and regenerability [17]. The adsorption process is a non-invasive approach which removes sulfur from liquid fuels under mild operating conditions and it in principle has potential for industrial desulfurization. Various research has been conducted to develop materials with high desulfurization capacity or efficiency however even highest efficiency, achieved thus far, is still insufficient for industrial applications. To increase the efficiency of adsorptive desulfurization method the adsorption capacity and sorbent regeneration should be further improved [25].

M.S. Patil et al. [26] reported the desulfurization of hydrocarbons liquid fuels via adsorption. Authors also have done the experiment in a batch reactor for soaking of compounds with sulfur content onto activated carbon, which was furnished with black liquor and phosphoric acid and nitrogen reactor used as the intercalating agent. They also studied, intra particle diffusion resistance has been overcome because of stirring and experimental data obtained by Langmuir adsorption isotherm model. Yoshie shimizu et al. [27] studied desulfurization of fuel oils such as kerosene and diesel oil be adsorption. Authors used rice husks which were carbonized in $\mathrm{N}_{2}$ at $400^{\circ} \mathrm{C}$ for $60 \mathrm{~min}$ and then were activated in $\mathrm{CO}_{2}$ at $850^{\circ} \mathrm{C}$ at $60 \mathrm{~min}$. the investigators also studied the capacity of rice husk activated carbons to adsorb organic sulfur compounds of Dibenzothiophene were determine by correlating with their textural properties and chemical characteristics. The rice husk activated carbon of $0.5 \mathrm{~g}$ was soaked in commercial kerosene of $15 \mathrm{~g}$ at $10^{\circ} \mathrm{C}$ for $100 \mathrm{~h}$. Jae Hyung Kim et al. [28] have studied adsorptive 


\section{International Journal of Science and Research (IJSR) \\ ISSN (Online): 2319-7064}

Index Copernicus Value (2013): 6.14 | Impact Factor (2015): 6.391

desulfurization and denitrogenation of diesel oil (containing refractory sulfur compounds) over three adsorbents such as activated carbon, activated alumina and nickel based adsorbent in fixed bed reactor. The investigator also studied adsorptive capacity and selectivity for different compounds on the basis of break through curves. The author also reported that activated carbon has high adsorptive capacity and selectivity for both organic sulfur and nitrogen compounds, especially for the organic sulfur compounds with the methyl groups such as 4,6-dimethydibenzothiophene(4,6DMDBT).

Souman Das Gupta et al. [29] reported adsorptive desulfurization of diesel by used of nickel-based adsorbent. The investigators reported that under optimized conditions (pressure 4 bar and temperature $350^{\circ} \mathrm{C}$ ) nickel based adsorbent(NiMCM-41) could reduce the sulfur concentration from $450 \mathrm{ppm}$ to $50 \mathrm{ppm}$. The adsorbent capacity and regenerability were examined by investigators, adsorbent regenerable under controlled oxidation with air at $450^{\circ} \mathrm{C}$ without loss of the sulfur removal capacity. A.B. Salem et al. [30] studied adsorption desulfurization of naphtha in a batch reactor by using of different solid sorbents such as activated carbon and zeolite 13X. Authors also reported that activated carbon showed high capacity but a low sulfur removal. Zeolite 13X was superior for sulfur removal from low sulfur streams at room temperature. The investigators used two bed combination for the industrial application. The first bed contains activated carbons and capacity to remove sulfur up to $65 \%$ at $80^{\circ} \mathrm{C}$ and the second bed carrying zeolite $13 \mathrm{X}$ which is able to remove sulfur content up to $100 \%$ at room temperature if the sorbent/feed ratio is bout $800 \mathrm{~g} / \mathrm{l}$

Isam A.H. et al. [31] have studied adsorption desulfurization of diesel oil by using of seven different solid sorbents such as Bentonite, Acid activated bentonite, date palm kernel powder, acid activated date palm kernel powder, saw dust powder, commercial powder and granules activated carbon. The experimental study conducted in batch reactor and amount of sorbent used in the range $0-5 \%$ by mass at room temperature with contact time $2 \mathrm{~h}$. Authors reported that commercial powder activated carbon got the highest sulfur removal capacity and sulfur content reduced from $410.9 \mu \mathrm{g} / \mathrm{g}$ to $245.9 \mu \mathrm{g} / \mathrm{g}$ by using of $5 \%$ mass commercial powder activated carbon and $278 \mu \mathrm{g} / \mathrm{g}$ using acid activated bentonite.

\subsection{Biodesulfurization (BDS)}

Biodesulfurization (BDS) has been studied an alternative to HDS, BDS is the most efficient process because of it takes place at low temperature and pressure in the presence of microorganism. In the BDS process bacteria used as a catalyst to remove the refractory sulfur compounds from liquid fuels. Caro et al. [32] studied that BDS requires approximately two times less capital cost and 15\% less operating cost in comparison with Hydro-desulfurization (HDS) process.

Even So BDS process applying microorganism biocatalyst suitable for desulfurizing of organic sulfur compound such alkylated DBT is good for this purpose and various studied had done by researchers on BT, DBT desulfurizing bacteria and their enzyme involved in removal of sulfur compounds from fuel. The life of microorganism in BDS process used to be short (1-2 days), but this has been extended to 8-16 days. However, current design allows the production and regeneration of the biocatalyst within the BDS process which provides 200-400 $\mathrm{h}$ biocatalyst life. [17]. The biodesulfurization process carried out in two phase system, whether whole cell used as biocatalyst in the aqueous phase interacts with oil phase $[4,33]$. Long ago only gram positive bacteria utilized for biodesulfurization of sulfur compounds.

Gunam et al. [34] applied gram bacteria (Sphingomonas subarctica T7b) for degradation of sulfur compounds (DBT, 4,6-dibutyl DBT and 4,6-Dipentyl BDT) from liquid fuels. They also studied the ability of Sphingomonas subarctica T7b by using of resting and immobilized cells with DBT, alkyl DBT and commercial light gas oil as the substrate. The resting cells of Sphingomonas subarctica $\mathrm{T} 7 \mathrm{~b}$ degraded the DBT from 250 to $239.2 \mathrm{mg} / \mathrm{l}$ within $24 \mathrm{~h}$ at $27^{\circ} \mathrm{C}$, while $127.5 \mathrm{mg}$ of 2-hydroxybiphenyl (2-HBP) was formed in the result 55\% DBT conversion achieved [30]. The investigators also investigate that cells immobilized by entrapment with polyvinyl chloride exhibit high desulfurization activity of DBT and it could be used more than 8 cycles. The stability of immobilized cells was better than that of resting cells at different $\mathrm{pHs}$, temperature, and DBT desulfurization. The desulfurization process carried out in two pathways: aerobic pathways (kodama pathways) and $4 \mathrm{~S}$ pathways (sulfur specific pathways) but most attention given to $4 \mathrm{~S}$ route for removal of refractory sulfur compounds from fuels. The pathway of $4 \mathrm{~S}$ include four consecutive reactions as shown in the Fig: 4 [32]. In beginning DBT is oxidized by two monooxygenases, DBT monooxygenase(Dszc), DBT sulfone monooxygenase (Dsza) and at the end converted to 2hydroxybiphenyl by the desulfinase(DszB).

Aribike et al. [35] reported the biodesulfurization(BDS) of diesel fuel by desulfobacterium anilini. The investigators also studied the used of desulfobacterium aniline isolated from petroleum products- polluted soil and the removal of sulfur containing hydrocarbons from diesel oil. Authors carried out experiments at $300^{\circ} \mathrm{C}$ and atmospheric pressure and concluded that the peaks of benzothiophene(BT), dibenzothiophene(DBT) in diesel oil decreases after applied of BDS process. Author reported that at the end of $72 \mathrm{~h}$ yield of diesel oil reached to $82 \%$. A newly identified bacterial strain Rhodococcus sp.(JUBT1) isolated from diesel oil, which has been utilized for different refractory sulfur compounds such as, DBT, alkylated DBT etc. and which basically not changed during hyodrodesulfurization of diesel oil. the desulfurization via microorganism of refractory sulfur compounds achieve to $1000-100 \mathrm{mg} / \mathrm{dm}^{3}$ in $24 \mathrm{~h} \mathrm{[36].}$ 


\section{International Journal of Science and Research (IJSR) \\ ISSN (Online): 2319-7064}

Index Copernicus Value (2013): 6.14 | Impact Factor (2015): 6.391

equal amount of 2-hydroxybiphenyl(HBP). Metabolizing enzymes having the maximum specific activity in the range 0.36-0.47 $\mu \mathrm{mol} \mathrm{HBP} \mathrm{min}^{-1}$. Author also studied bacterial growth by using of haladane type kinetics characterizing the presence of substrate inhibition.

Gupta et al. [38] reported the biodesulfurization of sulfur containing compounds such as DBT and its derivatives via kodama pathways. In this route or pathways initial oxidative $\mathrm{C}-\mathrm{C}$ cleavage, which involves ring cleavage of one aromatic ring in sulfur compounds as shown in the Fig: 5.

\section{Conclusion}

Different technologies were proposed for the desulfurization of liquid fuel. These technologies include Hydrodesulfurization, extractive desulfurization, oxidative desulfurization and adsorptive desulfurization. Among these desulfurization technologies few of the strategies are viable for the deep desulfurization of liquid fuels. Because of properties of liquid fuels like, high boiling point, more refractory sulfur content and the nature of refractory sulfur compounds.

\section{References}

[1] Phase, I., and Particulate Matter Emissions. "Diesel Emission Control-Sulfur Effects (DECSE) Program." (1999).

[2] Sengupta, Aryav, Prashant D. Kamble, Jayanta Kumar Basu, and Sonali Sengupta. "Kinetic study and optimization of oxidative desulfurization of benzothiophene using mesoporous titanium silicate-1 catalyst." Industrial \& Engineering Chemistry Research 51, no. 1 (2011): 147-157.

[3] Dharaskar, Swapnil A., Mahesh N. Varma, Diwakar Z. Shende, Chang Kyoo Yoo, and Kailas L. Wasewar. "Synthesis, characterization and application of 1-butyl-3 methylimidazolium chloride as green material for extractive desulfurization of liquid fuel." The Scientific World Journal 2013 (2013).

[4] Javadli, Rashad, and Arno de Klerk. "Desulfurization of heavy oil." Applied Petrochemical Research 1, no. 1-4 (2012): 3-19.

Figure 5: Biodesulfurization through Kodama pathways for DBT (a) dibenzothiophene; (b) cis-1,2-dihydroxy-1,2dihydrodibenzothiophene; (c) 1,2-dihydroxydibenzo thiophene; (d) cis-4- [2-(3 hydroxy) thioaphthenyl]-2-oxo-3butenoate; (e) trans-4-[2-(3-hydroxy) thioaphthenyl]-2-oxo3-butenoate; (f) 3-hydrooxy-2-formylbenzothiophene.

Fatemeh et al. [33] applied Rhodococcus erythropolis (SHT87) strain which was isolated from oil contaminated soils in Iran for biodesulfurization of organosulfur compounds. Rhodococcus erythropolis(SHT87) was found to three sulfur metabolizing genes such as DszA, DszB, DszC, which indicates that SHT87 strain converts dibenzothiophene to 2-hydroxybiphenyl(2-HBP) through $4 \mathrm{~S}$ pathway. Author studied growth of this strain in $5 \mathrm{~g} / \mathrm{L}$ glycerol as carbon source in $120 \mathrm{~h}$ by cultivation of organism in $120 \mathrm{~min}$, conversion was achieved to $30 \%$ which derived from the
[5] Corro, Griselda. "Sulfur impact on diesel emission control-A review."Reaction Kinetics and Catalysis Letters 75, no. 1 (2002): 89-106.

[6] Song, Chunshan. "An overview of new approaches to deep desulfurization for ultra-clean gasoline, diesel fuel and jet fuel." Catalysis today 86, no. 1 (2003): 211-263.

[7] Wang, Jianlong, Dishun Zhao, and Kaixi Li. "Oxidative desulfurization of dibenzothiophene catalyzed by Brönsted acid ionic liquid." Energy \& Fuels 23 , no. 8 (2009): 3831-3834.

[8] Chan, K., Jung J., Lee,J., Sang B., Kyungil, C. and Sang, H., Hydrodesulphurization of DBT, 4-MDBT, and 4,6DMDBT on fluorinated $\mathrm{CoMoS} / \mathrm{Al} 2 \mathrm{O} 3$ catalysts. Applied catalysis A. 2000, pp. 233-242.

[9] Paniv, P. M., S. V. Pysh'ev, V. I. Gaivanovich, and O. I. Lazorko. "Noncatalytic oxidation desulfurization of the 


\section{International Journal of Science and Research (IJSR) \\ ISSN (Online): 2319-7064}

Index Copernicus Value (2013): 6.14 | Impact Factor (2015): 6.391

kerosene cut." Chemistry and technology of fuels and oils 42, no. 3 (2006): 159-166.

[10]Huang, Chongpin, Biaohua Chen, Jie Zhang, Zhichang Liu, and Yingxia Li. "Desulfurization of gasoline by extraction with new ionic liquids." Energy \& Fuels 18, no. 6 (2004): 1862-1864.

[11]Zannikos, F., E. Lois, and S. Stournas. "Desulfurization of petroleum fractions by oxidation and solvent extraction." Fuel processing technology42, no. 1 (1995): $35-45$.

[12] Dhir, S., R. Uppaluri, and M. K. Purkait. "Oxidative desulfurization: Kinetic modelling." Journal of hazardous materials 161, no. 2 (2009): 1360-1368.

[13] Qiu, Jianghua, Guanghui Wang, Yuqin Zhang, Danlin Zeng, and Yang Chen. "Direct synthesis of mesoporous $\mathrm{H} 3 \mathrm{PMo} 12 \mathrm{O} 40 / \mathrm{SiO}_{2}$ and its catalytic performance in oxidative desulfurization of fuel oil." Fuel 147 (2015): 195-202.

[14] Jose, N., S. Sengupta, and J. K. Basu. "Optimization of oxidative desulfurization of thiophene using $\mathrm{Cu} /$ titanium silicate-1 by box-behnken design." Fuel 90, no. 2 (2011): 626-632.

[15]Jia, Yuhua, Gang Li, and Guiling Ning. "Efficient oxidative desulfurization (ODS) of model fuel with $\mathrm{H}_{2} \mathrm{O}_{2}$ catalyzed by $\mathrm{M}_{3} \mathrm{OO} / \gamma-\mathrm{Al}_{2} \mathrm{O}_{3}$ under mild and solvent free conditions." Fuel Processing Technology 92, no. 1 (2011): 106-111.

[16] Maity, Uttam, Jayanta Kumar Basu, and Sonali Sengupta. "Oxidative removal of dibenzothiophene from a model fuel using nanocrystalline Ti-beta catalyst." Journal of the Energy Institute (2015).

[17]Babich, I. V., and J. A. Moulijn. "Science and technology of novel processes for deep desulfurization of oil refinery streams: a review." Fuel 82, no. 6 (2003): 607-631.

[18] Funakoshi, Izumi, and Tetsuo Aida. "Process for recovering organic sulfur compounds from fuel oil." U.S. Patent 5,753,102, issued May 19, 1998.

[19] Bailes, P. J. "Solvent extraction in an electrostatic field." Industrial \& Engineering Chemistry Process Design and Development 20, no. 3 (1981): 564-570.

[20] Toteva, V., L. Topalova, and P. Manolova. "Extractive dearomatization and desulphurization of a distillate gasoil cut with dimethylformamide." Journal of the University of Chemical Technology and Metallurgy 42, no. 1 (2007): 17-20.

[21] Chen, Xiaochun, Shan Yuan, Ahmed A. Abdeltawab, Salem S. Al-Deyab, Jianwen Zhang, Liang Yu, and Guangren Yu. "Extractive desulfurization and denitrogenation of fuels using functional acidic ionic liquids." Separation and Purification Technology 133 (2014): 187-193.

[22] Bösmann, A., L. Datsevich, A. Jess, A. Lauter, C. Schmitz, and P. Wasserscheid. "Deep desulfurization of diesel fuel by extraction with ionic liquids." Chemical Communications 23 (2001): 2494-2495.

[23] Kim, Jae Hyung, Xiaoliang Ma, Anning Zhou, and Chunshan Song. "Ultra-deep desulfurization and denitrogenation of diesel fuel by selective adsorption over three different adsorbents: a study on adsorptive selectivity and mechanism." Catalysis Today 111 , no. 1 (2006): 74-83.
[24] Ng, Flora TT, Ataur Rahman, Tomotsugu Ohasi, and Ming Jiang. "A study of the adsorption of thiophenic sulfur compounds using flow calorimetry."Applied Catalysis B: Environmental 56, no. 1 (2005): 127-136.

[25]Blanco-Brieva, G., J. M. Campos-Martin, S. M. AlZahrani, and J. L. G. Fierro. "Removal of refractory organic sulfur compounds in fossil fuels using MOF sorbents." Global Nest J 12, no. 3 (2010): 296-304.

[26] Patil, M. S., Y. C. Bhattacharyulu, and S. R. Kulkarni. "Desulphurization of hydrocarbon liquid fuels by adsorption." Journal of Engineering Research and Studies, JERS 2 (2011): 81-98.

[27] Shimizu, Yoshie, Seiji Kumagai, and Koichi Takeda. "Adsorptive removal of sulphur compounds in kerosene by using rice husk activated carbon." Japan Energy Corporation, Toda: 335-8502.

[28] Kim, Jae Hyung, Xiaoliang Ma, Anning Zhou, and Chunshan Song. "Ultra-deep desulfurization and denitrogenation of diesel fuel by selective adsorption over three different adsorbents: a study on adsorptive selectivity and mechanism." Catalysis Today 111 , no. 1 (2006): 74-83.

[29] Dasgupta, Soumen, Pushpa Gupta, Anshu Nanoti, Amar N. Goswami, Madhukar O. Garg, Elisabeth Tangstad, Ørnulv B. Vistad, Arne Karlsson, and Michael Stöcker. "Adsorptive desulfurization of diesel by regenerable nickel based adsorbents." Fuel 108 (2013): 184-189.

[30] Salem, Abu Bakr SH, and Halim S. Hamid. "Removal of sulfur compounds from naphtha solutions using solid adsorbents." Chemical engineering \& technology 20, no. 5 (1997): 342-347.

[31] Al Zubaidy, Isam AH, Yasmin Mohamed Ali, Meera AlSuwaidi, Rayan Al Shaihk, Azeema Attari, and Leher Farooq. "Raghad Al-Sulh, TahaOzkul, Karma Zraqi, "Kinetics of novel adsorption desulphurization techniques for diesel fuel using different sorbents"." In International Conference on Chemical, Medical and Environmental Issues, p. 37.

[32] Caro, Ainhoa, Karina Boltes, Pedro Letón, and Eloy García-Calvo. "Dibenzothiophene biodesulfurization in resting cell conditions by aerobic bacteria." Biochemical engineering journal 35, no. 2 (2007): 191-197.

[33] Takada, Masaki, Nobuhiko Nomura, Hideki Okada, Toshiaki Nakajima-Kambe, Tadaatsu Nakahara, and Hiroo Uchiyama. "De-repression and comparison of oilwater separation activity of the dibenzothiophene desulfurizing bacterium, Mycobacterium sp. G3." Biotechnology letters 27, no. 12 (2005): 871-874.

[34] Gunam, I. B., Kenta Yamamura, I. Nengah Sujaya, Nyoman Semadi Antara, Wayan Redi Aryanta, Michiko Tanaka, Fusao Tomita, Teruo Sone, and Kozo Asano. "Biodesulfurization of dibenzothiophene and its derivatives using resting and immobilized cells of Sphingomonas subarctica T7b." J. Microbiol. Biotechnol 23, no. 4 (2013): 473-482.

[35] Kareem, S. A., D. S. Aribike, S. C. Nwachukwu, and G. K. Latinwo. "Microbial desulfurization of diesel by Desulfobacterium indolicum." Journal of environmental science \& engineering 54, no. 1 (2012): 98-103.

[36] Guchhait, Sugata, Dipa Biswas, Pinaki Bhattacharya, and Ranjana Chowdhury. "Bio-desulfurization of model organo-sulfur compounds and hydrotreated diesel- 
experiments and modeling." Chemical Engineering Journal 112, no. 1 (2005): 145-151.

[37] Davoodi-Dehaghani, Fatemeh, Manouchehr Vosoughi, and Abed Ali Ziaee. "Biodesulfurization of dibenzothiophene by a newly isolated Rhodococcus erythropolis strain." Bioresource technology 101, no. 3 (2010): 1102-1105.

[38] Gupta, Nidhi, P. K. Roychoudhury, and J. K. Deb. "Biotechnology of desulfurization of diesel: prospects and challenges." Applied microbiology and biotechnology 66, no. 4 (2005): 356-366.

\section{Author Profile}

Dr. Sunder Lal is Assistant Professor in Chemical Engineering Department, MANIT Bhopal, INDIA. He obtained his PhD from IIT Kanpur, India. He has more than ten years experienced of teaching and research. He has published more than ten international and national journal research papers.

Mr. Gulam Gaush Zeelani is pursuing $M$ Tech in Chemical Engineering Department from MANIT, Bhopal, India. 